Avi Rubin

\title{
6 The Slave, the Governor, and the Judge: An Ottoman Socio-Legal Drama from the Late Nineteenth Century
}

\subsection{Introduction}

Judge Ali Eşref Efendi, the respected president of the court of first instance in the Ottoman town of Ayvalık, may or may not have been surprised when the gendarmes came to arrest him on Wednesday, November 4, 1885. Forced to spend the next four months in prison, waiting for his trial to commence, he had plenty of time to ask himself over and over again whether his sacrifice on behalf of the female slave Bezmihal was justified. To be sure, his intentions were humane by every moral standard. A year earlier, a female slave (cariye) named Bezmihal had approached a judge's wife with a plea for immediate help. Her situation was rather complicated, since she had been in the service of the local governor of the county, Emin Bey, for the previous twelve years. Bezmihal told the judge's wife that her master, the governor, after formally manumitting her, had changed his mind and decided to sell her. She also complained about the brutality with which she had been treated. Why did Bezemihal appeal to the wife rather than the judge? The details that unfolded during the trial strongly suggest that her decision to approach the judge through his wife was a calculated move, one in a series of moves intended to fulfill the universal desire of slaves for freedom.

Judge Eşref Efendi was accused of violating a major procedure by having the court issue a ruling that was supposed to secure Bezmihal's freedom and prevent her sale. From the perspective of the public prosecutor, the problem was not the fact that the Ayvalık court of first instance had intervened on behalf of the slave, which, in itself, was in line with the overall slow-but-steady process of abolition which took place in the late nineteenth century. The problem was entirely legal. The court president was accused of issuing a court decision on his own initiative without following the standard procedure, which required a court hearing.

The verbatim report of the trial of Ali Eşref Efendi was published in the Ceride-i Mehakim (Journal of the Courts), published by the Ottoman Ministry of Justice for the judicial community of the empire. The trial tells the interrelated stories of a female slave who desired freedom, her master, a local governor who was ambivalent about her manumission, and a judge who risked his career on her behalf. At the same time, the trial reflects two major transformations that were part of the passage of Ottoman society to modernity: the abolition of slavery and judicial reform. The trial of Ali Eşref Efendi provides an opportunity to discuss some key features of Ottoman

(cc)BY-NC-ND (c) 2015 Selection and editorial matter: Dror Zeevi and Ehud R. Toledano; individual contributors, their contributions. 
legal changes and how they were experienced by ordinary people who were forced to deal with the dilemmas brought about by new laws, major reforms, and a new legal culture.

A comment should be made about the approach employed in this article. Overall, microhistorical methods are seldom applied in historical writing about the modern Middle East, leaving questions of individual agency and everyday practices relatively neglected. ${ }^{1}$ Microhistory emerged in the 1970 s as an alternative to the generalizations made by social scientists, which, according to microhistorians, failed to capture "the concrete reality of the small-scale life they wished to explain." 2 This approach has since evolved into a diverse genre of historical writing offering a wide range of methodologies and objectives, defying any attempt to subject microhistory to one definition. ${ }^{3}$ Nevertheless, it seems that recovering human agency through scale reduction is the single most salient feature of all microhistories. Texts analyzed microhistorically are not meant to "represent" the greater whole in the way that case studies serve social scientists. Rather, the scale reduction and the narrative strategies employed allow us to imagine the episode in question and the world in which it was set. Equally significant, it enables us to imagine the dilemmas and choices faced by ordinary people in the wake of major transformations.

My discussion begins with a general review of the judicial reforms, followed by a discussion of the events leading up to the trial and the choices made by the individuals involved in the events that led to the trial, and in the proceedings themselves. This allows me to demonstrate something of the dynamics of modern Ottoman courts.

1 Notable exceptions are the following microhistorical studies, all of which focus on socio-legal themes: Ehud R. Toledano, As if Silent and Absent: Bonds of Enslavement in the Islamic Middle East (New Haven, 2007); Ehud R. Toledano, "Slave Dealers, Pregnancy, Abortion, and the World of Women: The Story of a Circassian Slave Girl in mid-Nineteenth Century Cairo," Slavery and Abolition 2 (1981): 53-86; Iris Agmon, Family and Court: Legal Culture and Modernity in Late Ottoman Palestine (Syracuse, 2006); Leslie P. Peirce, "Le dilemma de Fatma: Crime sexuel et culture juridique dans une cour ottoman au debut de temps moderns," Annales: Histoire, Sciences, Sociales 53 (1998): 291-320; Leslie P. Peirce, Morality Tales: Law and Gender in the Ottoman Court of Aintab (Berkeley and Los Angeles, 2003).

2 George G. Iggers, Historiography in the Twentieth Century: From Scientific Objectivity to the Premodern Challenge (Hanover NH, 1997), 108.

3 The large volume of methodological discussions on microhistory is indicative. See, for instance Giovanni Levi, "On Microhistory," in New Perspectives on Historical Writing, ed. Peter Burke (Cambridge UK: Polity Press, 1991), 93-113; Thomas Kuehn, "Reading Microhistory: The Example of Giovanni and Lusanna," The Journal of Modern History 61 (1989): 512-534; Brad S. Gregory, "Is Small Beautiful? Microhistory and the History of Everyday Life," History and Theory 38 (1999): 100-110; Carlo Ginzburg, John Tedeschi, and Ann C. Tedeschi, "Microhistory: Two or Three Things that I Know about It," Critical Inquiry 20 (1993): 10-35; John Brewer, "Microhistory and the Histories of Everyday Life," Cultural and Social History 7 (2010): 87-109; Sigurdur Gylfi Magnusson, "The Singularization of History: Social History and Microhistory within the Postmodern State of Knowledge," Journal of Social History 36 (2003), 701-735. 
Specifically, in the last part of my discussion, I interpret the trial as an illustration of the new legal culture that emerged in the 1870s, which emphasized formalism and accountability.

\subsection{New Courts}

Until the second half of the nineteenth century, Ottoman law, which was a combination of Şer'i law and sultanic edicts legislated at the imperial center, had been applied through the Şeriat courts. During the second half of the nineteenth century the Ottoman judicial system was comprehensively restructured as part of the administrative reorganization of state institutions, known as the Tanzimat (reorganization). A new court system evolved during the 1850s and the 1860s through a heuristic process which began with the establishment of judicial forums for solving disputes between Ottoman and foreign subjects, particularly in the field of commerce, and matured with the foundation of the Nizamiye courts in 1864, and the judicial reforms of 1879. Legal borrowing from French law, codification in the civil, criminal and commercial fields, and standardization in the working of the courts were at the core of this major legal change. ${ }^{4}$

The reforms of 1879 brought the judicio-administrative evolution of the Nizamiye court system to its conclusion by introducing civil and criminal procedural codes and establishing a formal division of labor between the Nizamiye and the Seriat courts. The jurisdiction of the Şeriat courts was reduced to matters of personal status, whereas the Nizamiye courts became the main judicial forum for addressing civil and commercial cases, and the exclusive forum in the criminal domain. ${ }^{5}$

Scholars of the modern Middle East have interpreted the Ottoman adoption of French laws and concepts as a sign of partial secularization and westernization, often describing the Nizamiye courts as "secular courts". Elsewhere I criticize the accustomed tendency to frame the otherwise multi-faceted process of socio-legal change in

\footnotetext{
4 On the emergence of the Nizamiye courts and their institutional structure, see Sedat Bingöl, Tanzimat Devrinde Osmanl'da Yargı Reformu: Nizamiye Mahkemelerinin Kuruluşu ve İşleyisi 18401876 (Eskişehir: Anadolu Üniversitesi, 2004); Ekrem Buğra Ekinci, Osmanl Mahkemeleri (Istanbul: Arı Sanat, 2004); Fatmagül Demirel, Adliye Nezareti: Kuruluşu ve Faaliyetleri, 1876-1914 (Istanbul: Boğaziçi, 2007). On the socio-legal history of the Nizamiye courts, see Avi Rubin, Ottoman Nizamiye Courts: Law and Modernity (New-York: Palgrave Macmillan, 2011).

5 The state allowed a certain space for legal pluralism in specific civil matters, thus permitting litigants to choose between the Nizamiye and the Şeriat courts. See Rubin, Ottoman Nizamiye Courts; Iris Agmon, Family and Court: Legal Culture and Modernity in Late Ottoman Palestine (Syracuse: Syracuse University Press, 2006).
} 
terms of the ever-present duo of westernization/secularization. ${ }^{6}$ In my understanding of the Nizamiye courts, the descriptive categories of westernization and secularization possess little value for understanding the working of these new courts and their role in the overall passage of Ottoman law to modernity. Indeed, akin to other projects of legal change in the history of the world, the Ottoman case of judicial reform was embedded in legal borrowing; and like all other cases of legal borrowing, the resulting judicial system was an amalgam of local and borrowed laws and practices, rather than a replication of the model legal system. The Nizamiye court system manifested such hybridity in the laws it applied and in its structure. The expansive corpus juris employed by the courts for the purpose of adjudication included codified Şer'i law, such as the Mecelle (the civil code), alongside codified adaptations of French law, such as the Code of Civil Procedure. Of special relevance to the episode discussed in this paper is the Ottoman version of the courts of first instance, which was an adaptation of the French equivalent.

Unlike the Şeriat court, which was administered by a single judge (kadl, hence widely referred to as "kadi courts"), each Nizamiye court consisted of a few members ( $a z a$ ) and a president (reis). The number of members reflected the level of the court in the judicial hierarchy. Thus, the court of first instance consisted of two members and a president; the provincial courts of appeal were divided into civil and criminal sections, each of which consisted of four members and a president; each section in the Court of Cassation in the imperial capital, which was the highest judicial level, consisted of six members and a president. The courts of first instance were the backbone of the system and manifested an intriguing feature: most of the judges presiding in these courts were the local Şer'i judges (naibs). In other words, the presidents of the Nizamiye courts of first instance were the same individuals who served in the local Şeriat court. When serving in the Şeriat court, the naib worked in accordance with Şer'i procedure; when presiding the Nizamiye courts, he was expected to apply the positive law that was distinctive of the Nizamiye courts. ${ }^{7}$ This composition of the courts of first instance changed in the years following the Young Turks Revolution (1908), when the positions of presidents were filled by judges of non-Şer’i educational background. ${ }^{8}$ Hence, there was nothing unusual in the fact that Ali Eşref Efendi, who presided over the Nizamiye court of first instance in Ayvalık, was a naib by training.

\footnotetext{
6 Avi Rubin, “Ottoman Judicial Change in the Age of Modernity: A Reappraisal," History Compass 7 (2009): 119-40.

7 In a few courts, however, the president of the court of first instance was not a naib. See, for instance, Diyarbakur Salnameleri, 1286-1323, ed. Ahmet Zeki İzgöer, vol. 3 (Diyarbakır: Diyarbakır Büyükşehir Belediyesi, 1999), 305; Konya Vilayet-i Salnamesi (Konya: Konya Vilayet Matbaası, 1315). 8 Demirel, Adliye Nezareti’nin Kuruluşu ve Faaliyetleri, 89-90.
} 


\subsection{The Trial of Ali Eşref Efendi}

The verbatim report of the trial appeared in the Ceride-i Mehakim (Journal of the Courts, est. 1873), an official publication issued by the Ministry of Justice. This weekly publication was an important tool, designed to promote some of the key objectives of the reforms, notably standardization of judicial practice and effective communication between the various judicial units. The journal helped hundreds of judges, clerks, prosecutors, notaries and attorneys to find their way through the Nizamiye procedural maze. The voluminous issues of the Ceride contain thousands of reports on cases originating from courts of first instance and courts of appeal across the empire. Most of the case reports appear as concise minutes, but in a few cases the editors chose to publish complete verbatim reports of court hearings, as was the case with the trial of Ali Eşref Efendi, due to the trial's exemplary value.

\subsubsection{The Charges}

Ayvalık is an ancient seaside town on the northwestern Aegean coast of Anatolia. In the late nineteenth century it belonged to the province of Hüdavendiğar. Ali Eşref was tried in the criminal section of the court of first instance in Karesi (today's Balıkesir), which was the provincial capital of Hüdavendiğar. The first hearing only took place four months after his detention, because Ali Eşref Efendi had, for unknown reasons, submitted a petition to the Court of Cassation, asking for his case to be transferred to another court, a petition which had been denied. The trial commenced on March 22.

The Karesi staff consisted of four court members and a president, a recording clerk, and an assistant public prosecutor. As described in the report, facing them was the accused judge, Ali Eşref Efendi, alongside his Greek attorney, Toma Andonyadi Efendi (who was later replaced by another attorney). The hearing was public, as was the case with most Nizamiye trials. The courtroom contained sixty spectators, seated to the left of the table that stood between the accused and the court panel. More spectators were seated behind the accused and his attorney. The court president, Ali Riza Efendi, administered the trial in accordance with the Nizamiye procedure. He started by asking the accused to state his name, age, occupation, address and place of birth. Ali Eşref Efendi indicated Istanbul as his place of birth and permanent residence. Once the procedure of identification was completed, the president instructed the prosecutor to present his case.

As a rule, in accord with the impersonal discursive style of the Continental legal tradition, recorded statements by public prosecutors in court were neutral, their tone devoid of condemnation. However, the public prosecutor, Ali Haydar Bey, deviated from this style, when making the following introduction: 
Obviously, the foundation and publication of laws are intended to secure public and private rights. Courts are established and judges are appointed to carry out the rule of justice... However, Ali Eşref Efendi, the previous president of the Ayvalık court of first instance, chose to act contrary to the law, which is a violation of one of the most important judicial qualities, if not the most important one. ${ }^{9}$

In all criminal cases, the onus was on provincial public prosecutors and their assistants to represent the "public rights" in court on the basis of an investigation conducted by the investigating magistrate (müstantık); in cases of accusations against judicial officials, however, the decision whether or not to press charges was contingent on an investigation conducted by an ad hoc committee (heyet-i mahsusa). The prosecutor summarized the bill of indictment, which included the following three charges: first, on July 1884, Ali Eşref issued a Nizamiye court decision concerning the freedom of Bezmihal, the female slave of the county governor (kaimakam) of Ayvalık, Emin Bey. This decision was conceived illegally, as it had not been preceded by a court hearing. Secondly, in his capacity as court president, Ali Eşref was accused of violating the orders of the Ministry of Justice by allowing the assistant examining magistrate of his court to travel to İzmir, and also allowing his court notary to travel to Istanbul. The public prosecutor argued that the court president had no authority to authorize these trips without the ministry's formal permission. Thirdly, Ali Eşref was accused of destroying a report submitted to him by the examining magistrate of his court. The first charge, defined by the prosecutor as cinayet-a transgression of the severest legal category-was the main issue in this trial, whereas the other charges were considered minor. The judge, Ali Riza, ordered the accused, Ali Eşref, to explain the issuance of the court decision concerning the freedom of the female slave, Bezmihal, to which Ali Eşref replied:

One day, Bezmihal, the female slave of Emin Bey, came to my wife and told her: "Although I have been in Emin Bey's service for twelve years, he wants to sell me now. Please manumit me." Several days later, the governor and his female slave came over [to my house]. During the discussion, the governor Bey told [Bezmihal]: "I manumitted you." Since she said that she was not sure that a Şer’i ruling was sufficient for [legal] manumission, I ordered [the court member] İkonomidi Efendi to write an official order (tenbihname). ${ }^{10}$

At this point, the court president ordered the clerk to read aloud the court decision in question, the summary of which is included in the protocol:

Following the petition of the female slave, the governor had been informed about the imperial orders concerning the prohibition on selling slaves, yet he admitted that he had intended sell her [nonetheless], being his female slave. Since he was reluctant to manumit her (itaktan istinkaf eylemesine mebni), the court decided to prevent the sale and confirm her personal freedom (hür-

9 Ceride-i Mehakim (henceforth, CM), 3,504.

$10 \mathrm{CM}, 3,505$. 
riyet şahsiyesi), in accordance with clauses 9 and 10 in the Essential Law (Kanun-ı Esası). The decision was dated 17 Temmuz 1300 [July 29, 1884]. ${ }^{11}$

In other words, at some earlier point, the governor had manumitted Bezmihal in the presence of the Şeri judge, who was one of Ali Eşref's predecessors, yet Bezmihal did not leave her master's house. The governor later changed his mind about her manumission, and decided to sell Bezmihal for unknown reasons. For Bezmihal, this act meant a perpetuation of her previous slave status, and a denial of her new status as a free woman.

\subsubsection{Slavery and Abolition}

Bezmihal's motivation in reaching out to the Nizamiye court, and judge Ali Eşref's response to her plea, make sense when contextualized by briefly describing the changes that occurred in Ottoman slavery during the second half of the nineteenth century. Slavery was a fundamental institution in Ottoman society since the foundation of the Ottoman state. Historians distinguish between the category of military-administrative servitude, known as the kul system, which was the linchpin of Ottoman military-administrative elite until the nineteenth century, and the category of domestic-agricultural slavery. In fact, the elevated social status of the former group has led some historians to question the validity of the term "slavery" for describing the kul system. $^{12}$

From the early 1840s, the Ottoman government was forced to accommodate increasing British abolitionist pressure. Attempting to resist British demands for suppression of slave trade in their domains, the Ottomans tried to persuade British statesmen and consuls that Ottoman slavery bore no resemblance to Western forms of slavery, by drawing their attention to the elite status of the kul category and playing down the significance of domestic-agricultural slavery. ${ }^{13}$ In the long run, however, the combination of unwavering British pressure, steady percolation of abolitionist ideas into Ottoman elite circles and intelligentsia, and the emerging Ottoman version of official nationalism, changed attitudes towards slavery in the nineteenth centu-

11 Ibid.

12 Gibb and Bowen, Islamic Society and the West, volume 1, 43-5. For the same reason, in her recent textbook on the Ottoman Empire, Suraiya Faroqhi avoids the term slaves when describing Janissaries, using instead a somewhat ambiguous formulation as to their actual legal status: "Janissaries and other office-holders of the sultan were so dependent on him that their condition bore a resemblance to slavery. In this regard, the levy of boys was in line with the Medieval Near Eastern tradition of using slaves or former slaves of the ruler for military functions." Suraiya Faroqhi, The Ottoman Empire: A Short History, trans. Shelley Frisch (Princeton: Markus Wiener, 2009), 48.

13 Ehud R. Toledano, Slavery and Abolition in the Ottoman Middle East (Seattle: University of Washington Press, 1998), 15. 
ry. ${ }^{14}$ On a practical level, this change took the form of edicts prohibiting slave trade, embedded in Anglo-Ottoman conventions; at the same time, it meant a more profound, indeed a historic transformation of the relationship between the state and the slaves, one whose reverberation is clearly apparent in Bezmihal's plea and the response of Judge Ali Eşref.

In his definitive social history of slavery in the late Ottoman Empire, Ehud Toledano analyzes the changing patterns in the relationship between what he terms the "patron state" of the Tanzimat and the large population of domestic-agricultural slaves. Conceptualizing the slaver-enslaved relationship as a "bond of reciprocity between unequal participants”. Toledano demonstrates how the state gradually backed down from its traditional support of slave owners, assuming the role of a patron of the slaves. Through interventions such as legislation and court decisions, the state claimed a new protective role with regard to slaves: "when approached by absconding enslaved persons, the tanzimat-state offered protection and benevolencethat is, manumission and responsible placement." ${ }^{15}$ In the second half of the century, it became a common practice for courts and officials to issue manumission documents, and related procedures were legislated concurrently. ${ }^{16}$ Slaves were quick to recognize the new official attitude to enslavement and the opportunity it entailed for improving their situation. They also identified the potential benefit of official documents in their dealings with officials and slave owners. In cases of manumission, the official document was their ticket to freedom. Hence, they “... remained keen on obtaining official papers of manumission, trying as best as they could to hang on to them or-if the papers were taken and torn-to reclaim their freedom on the basis of the destroyed papers." 17

The willingness of the reformers to regulate and even reduce the volume of the slave trade, and the slaves' attempts to attain freedom on the basis of this official approach, were often crushed by the reality of slave owners' indifference to manumission documents. As noted by Toledano, slave owners often considered these documents as a mere formality in cases of forced liberation by the state. ${ }^{18}$ This corresponds to Bezmihal's situation. She managed to attain a formal manumission docu-

14 Dror Ze'evi, “Kul and Getting Cooler: The Dissolution of Elite Collective Identity and the Formation of Official Nationalism in the Ottoman Empire," Mediterranean Historical Review, 11(1996): 177-95.

15 Ehud R. Toledano, As if Silent and Absent: Bonds of Enslavement in the Islamic Middle East (New Haven: Yale University Press, 2007), 111.

16 According to Erdem, "automatic manumission" was more widespread in Istanbul, the Balkan provinces and Western Anatolia, than in the Arabic speaking provinces. Y. Hakan Erdem, Slavery in the Ottoman Empire and its Demise, 1800-1909 (New York: Macmillan; St. Martin's Press, 1996), 154-60.

17 Toledano, As if Silent and Absent, 116.

18 Ibid. 
ment from the Şeriat court, yet her owner changed his mind about her manumission, disregarding the formal document in her possession. She reacted by absconding and trying to obtain another document of manumission.

\subsubsection{Bezmihal}

Was Bezmihal one of those absconding slaves who hoped to benefit from the new official attitude to slavery? The deposition taken from Judge Ali Eşref before the trial (read aloud at the trial), his statements in court, and the testimony of thirty-five year old court member İkonomidi Efendi, provide a consistent picture of the course of events. After several years of servitude, the governor Emin Bey manumitted his female slave, Bezmihal, in the presence of the naib; but she did not leave his household.

Who was Bezmihal, the daughter of Abdah? Her identity can be only inferred from the report. In the nineteenth century, cariye was a general term for female slave; in itself, it did not provide any clues about social standing. ${ }^{19}$ A cariye could be a member of the imperial elite, an upper-level harem slave in the household of a provincial high-ranking official, or a domestic servant of lower status. Emin Bey's handling of the issue suggests that Bezmihal belonged to the category of harem slaves, namely, women who were taught the social and domestic roles associated with the position of an "Ottoman lady," and eventually became the legal wives or concubines of members of the military-administrative elite. ${ }^{20}$ We may assume that Bezmihal was light-skinned, probably either Circassian or Georgian, given the common preference of elite households for light-skinned female-slaves. ${ }^{21}$

\subsubsection{A Compassionate Judge}

At some point, Bezmihal fled to the house of Ali Eşref Efendi, the local naib and president of the Nizamiye court in Ayvalık. She made the initial contact not with the judge, but with his wife, who apparently advised her to approach her husband. The report makes it clear that she spent some time in the house of the judge and his wife after running away from her master. One can only speculate why she chose to turn to the judge's wife first. Given the fact that she had already gone through the legal process of manumission, it was unlikely that she did so out of ignorance regarding her right to approach the judge directly. Perhaps the judge's wife was acquainted with Bezmihal; perhaps the judge's wife was known for her empathy. Whatever the reason, it is

19 Toledano, Slavery and Abolition, 167.

20 Ibid, 30.

21 Toledano, As if Silent and Absent, 12. 
clear that Bezmihal's decision to first approach the wife of judge Ali Eşref was a calculated move. Following his wife's suggestion, Bezmihal approached the judge. She told him that Emin Bey, her master, had changed his mind about her manumission and decided to sell her, and that he had been treating her with brutality.

Judge Ali Eşref Efendi did not find anything odd in her complaint. Sexual and other harassment of harem slaves was a common misfortune. ${ }^{22}$ Judge Ali Eşref stated in his deposition that the slave Bezmihal turned to the Nizamiye court with a plea to "rescue her from oppression," complaining that her master had been treating her with brutality, and that he intended to sell her. The judge responded to Bezmihal's request by providing her with a manumission document that was supposed to prevent her sale on the basis of the Essential Law of 1876, which prohibited violation of personal liberty. ${ }^{23}$ The benevolent intentions of Ali Eşref Efendi towards the woman in distress were evident in the testimony of court member İkonomidi Efendi, who recalled Ali Eşref's words to him following Bezmihal's plea:

\begin{abstract}
One day, Eşref Efendi came from his home and entered the courtroom in a state of agitation. He pulled out a piece of paper from his pocket and told me: "write what I am telling you." I picked up a pen. He ordered: "a one-paragraph Nizamiye ruling (ilam) has to be written concerning the freedom of Bezmihal, the female slave of Emin Bey. Put the decision in the register, and have it signed with the seals of the court members.” I warned Ali Eşref Efendi that this [action] would contradict the norm (hilaf-i vaki'); that the [other] members would disagree, and that this was a big responsibility. He replied: "I cannot punish the governor [for his violent treatment of Bezmihal]. I just want to protect his slave from slavery (ancak cariyeyi esaretten kurtarmak istiyorum). This slave escaped from the governor's house and took refuge with my wife. I am not sending her back to the governor's house. Governor Emin Bey has beaten her."24
\end{abstract}

It appears from this testimony that what most troubled Ali Eşref was the violence with which the governor treated his female slave. In fact, Ali Eşref Efendi was so moved by Bezmihal's story and so eager to save her from the alleged maltreatment of her master, that he was willing to violate procedure and issue a court ruling without first conducting a hearing. The court member warned him from the potential consequences but Ali Eşref chose to ignore them. The report does not disclose the reasons for Ali Eşref's reluctance to keep his court members in the picture. Given that, unlike presidents, court members were not professional lawyers, but rather elected representatives of the local elite appointed by special committees, one can imagine Ali Eşref's concern. Members of the local administrative councils and the courts of first instance were active participants in local politics. The provincial reforms of the 1860 s were intended, inter alia, to centralize political power by co-opting provincial power holders into the

22 Toledano, Slavery and Abolition, 30.

$23 \mathrm{CM}, 3,509$.

$24 \mathrm{CM}, 3,507$. 
state apparatus. ${ }^{25}$ As far as the local notables were concerned, membership in local administration became a means of preserving political power. ${ }^{26}$ Perhaps Ali Eşref Efendi, who, not being a native, was unaffected by local political games, assumed that the governor would thwart his attempt to help Bezmihal the moment he heard about it, by exerting his influence on the members of the court. Be that as it may, he seems to have felt sufficiently confident to confront the powerful official by this act. At that point, judging by the governor's reaction, the exchange between the judge and the governor did not appear to be a full confrontation. According to the testimony of Abd'almu'min Bey, a tax official who was an associate of governor Emin Bey, the governor told him that his slave had escaped to the judge's house, asking Abd'almu'min and another official to accompany him to the judge and help him persuade her to return. Abd'almu'min told the court what happened at the meeting at the house of the judge to render the governor's efforts worthwhile:

The governor tried to convince her, saying: "you are one of my children," but she refused. He told her that he will not beat her again. [Eventually] the judge sent [the slave] to the governor's house, accompanied by a Christian woman called Katarina. ${ }^{27}$

\subsubsection{Governor Emin Bey}

There is no way to know what was actually said at that meeting, and why the judge eventually decided to send Bezmihal back to Emin Bey against her will. Did Emin Bey threaten him in any way? Was the judge convinced by Emin Bey's pledge to never again beat Bezmihal? What was the nature of the relationship between Bezmihal and the governor? Surely, he did not take her leaving lightly. Her situation was tenuous and unclear, as were the circumstances of many other manumitted slaves, both male and female. It is clear that legally Bezmihal was a free woman after her master manumitted her in the presence of a Şer’ $i$ judge. Yet in actual fact, neither governor Emin Bey nor Bezmihal understood the formal manumission in the presence of the Şer' $i$ judge to be "the last word" on their bond. She is referred to as "Emin Bey's female slave (cariye)" throughout the protocol of the trial. Toledano's conceptualization of ownerslave relations as a "bond of reciprocity between unequal participants," dictated by the logics of patronage, is essential to understand Bezmihal's behavior. The formal

25 Carter V. Findley, "The Evolution of the System of Provincial Administration as Viewed from the Center," in Palestine in the Late Ottoman Period: Political, Social, and Economic Transformation, ed. David Kushner (Jerusalem: Yad Yizhak Ben-Zvi; Leiden: E.J. Brill, 1986), 4-29.

26 See, for instance, M. Safa Saracoğlu, "Letter from Vidin: A Study of Ottoman Governmentality and Politics of Local Administration, 1864-1877” (Ph.D. Dissertation, Ohio State University, 2007).

27 CM, 3,509-10. 
act of manumission cannot be interpreted merely in terms of shifting from one legal situation (enslaved) to another (freeman or freewoman), at any rate not by default. The question of Bezmihal's legal status was but one aspect, albeit an important one, of a complicated relationship between two individuals. This was also implied by the fact that she did not leave Emin Bey's house as soon as he had manumitted her.

Bezmihal approached the judge in order to put an end to the violent conduct of Emin Bey. Perhaps she hoped that he would help her find a better placement. Perhaps she had no intentions of leaving the governor's house in the first place. Yet, appealing to the judge (first to his wife) made perfect sense. After all, who else could she turn to? For her, Judge Ali Eşref Efendi represented the patron state, and he responded positively by providing her with legal assurance of her freedom. ${ }^{28}$ Nevertheless, he found out the hard way that the same state took its commitments to legal formalism no less seriously than its obligations to the enslaved.

Governor Emin Bey was not willing to tolerate the active role played by Judge Ali Eşref Efendi. According to the testimony of court member İkonimidi Efendi, once the governor learned about Ali Eşref's violation of procedure when issuing the court decision, he turned to the public prosecutor in the provincial center, determined to initiate the judicial process that would result in Ali Eşref Efendi's arrest. ${ }^{29}$

\subsubsection{Court Investigation}

The court that tried Ali Eşref was not interested in the question of Bezmihal's freedom, but with the legality of Ali Eşref's conduct. The president, Ali Rıza Efendi, and the members of his court had to decide whether or not Ali Eşref Efendi had issued an unlawful court decision. The information available to the court panel that tried Ali Eşref consisted of the various documents at hand (reports of the examining magistrate and prosecutor, depositions, minutes of the hearings), and the testimonies heard in court.

İkonomidi Efendi, a member in Judge Ali Eşref's court, was a key witness, since he was the only one who had been personally involved in the issuance of that court ruling. İkonomidi told the court that Ali Eşref dictated to him a Nizami court decision concerning the freedom of Bezmihal. Judge Ali Eşref dismissed this testimony as untrue. He said in the hearing that he had not dictated anything to İkonomidi, and that he merely asked him to have the Şeriat court write a proclamation that would reaffirm Bezmihal's freedom in order to prevent her sale, and inform the governor

28 Though the "patron-state" was a feature of the nineteenth century, Ottoman slaves always had the right to seek the protection of the courts and request manumission in cases of ill-treatment. Erdem, Slavery in the Ottoman Empire, 33.

29 CM, 3,508. 
accordingly. Trying to get to the bottom of this matter, the court president asked Ali Eşref: "Does İkonomidi Efendi hold a grudge against you?" and Ali Eşref replied: "I do not know whether or not he holds a grudge against me." Following this exchange, the prosecutor Ali Haydar Bey asked the judge to have the clerk read aloud the written deposition of Ali Eşref, and the judge complied.

As might be expected, the written defense that Ali Eşref had submitted to the court prior to the hearing was more structured than his more spontaneous oral statements in response to the queries of the president in the hearing, and it was certainly more legalistic in style:

First, there had been no court decision that was allegedly forged, and the alleged charge of forgery had not been founded; secondly, the responsibility (memuriyet) of setting up the court decision is demonstrated in the Criminal Code. In these circumstances, in order to inflict the [relevant] legal penalties on the perpetrator (fa'il), and especially in the case of forgery, the forger of the documents must be an official. Court decisions issued by the courts of first instance are kept in the courts. The preparation of reports, as well as all the duties related to the scribal actions, is not supposed to be referred to the court presidents. All of these responsibilities are exclusively among the duties of the head clerk (başkatib) and the recording clerk (zabit katibi). Hence, attributing the responsibility stemming from the act of the head clerk - defined here as a witness - to someone else, is inconceivable. [In addition], this matter is considered to belong to the Şeriat court. Since a Şeriat court decision had been already issued, the interested party (zat-l maslahat) does not need a Nizamiye court decision, unless he has a malicious intention, and he wishes to achieve a certain goal. It is apparent that the document mentioned above was not forged. The damaged person and the [actual] damage should be proven. All the details of the clauses regarding forgery are presented in clause 56 in the Code of Civil Procedure, and in the fourth chapter of the Code of Criminal Procedure. As to the abovementioned document, even if the private plaintiff was able to demonstrate to the court a forgery, he was unable to prove a malicious intention. ${ }^{30}$

To sum up, Ali Eşref made two arguments. Whereas the prosecution claimed that he had forged a Nizamiye decision, he tried to present the document that had been issued to Bezmihal as a Şer’i document, whose issuance was an administrative matter that was part of the scribal duties and not one of own responsibilities as a judge. If there was a procedural fault, it was a matter of error, and did not arise from malicious intent, which otherwise had to be proven. Obviously Ali Eşref was familiar with the formalist culture of the Nizamiye courts, and he played this card when stating his awareness that it was illegal for a judicial forum to decide on a matter that had already been decided in another judicial forum. It was only natural that he would employ his legal knowledge when arguing that actual damage had to be substantiated, and a damaged party had to be established, in order to prove his culpability.

Yet, Ali Eşref was a naib and a president of the civil Nizamiye court, not the criminal one. In fact, he seemed to be ill-informed on criminal law. Raising the issue of

30 CM, 3,511-2. 
"damaged party" made sense in Nizamiye civil cases, not in criminal ones, where the business of prosecution was exclusively in the hands of the state. Indeed, prosecutor Ali Haydar Bey exposed the legal ignorance of the accused judge, and his attempt to manipulate the court, when telling the court that the charges against Ali Eşref were "matters of public rights, and therefore there is no need to seek an injured party or a private plaintiff". ${ }^{31}$ The prosecutor did not spare any efforts to depict Ali Eşref's terminology and the statement concerning his commitment to the division of labor between the Şeriat and Nizamiye courts as an empty quibble. He was condemning the attempt of the defendant to present the document that had been provided to Bezmihal as a "written order" (tenbihname), rather than a court ruling (ilam): Using the word 'written order' (tenbihname) to describe this measure is a forced explanation after the fact. "Altogether, the case against Ali Eşref Efendi and the present trial is a Nizamiye matter; it is not related to the Şeriat court (niyabet-i Şeri'iye)." ${ }^{32}$ The other charges against Ali Eşref Efendi related to administrative irregularities in his court. Rather than denying these irregularities, he presented them as unfortunate mishaps.

\subsubsection{Decision}

As required by procedure, before concluding the hearing the president of the court asked Ali Eşref for the last time if he had anything else to say in his defense. The accused judge replied: "I have made my defense. I have nothing else to say". ${ }^{33}$ The president pronounced the conclusion of the hearing, and retired with his colleagues to the conference room, where they deliberated the case and drafted the decision.

The court was not convinced by Ali Eşref's explanations. In its decision, it pointed to the series of procedural violations of which he was accused. In addition to the charges that sparked the proceedings against Ali Eşref Efendi, the court stated in its decision that Ali Eşref had ignored the formal division of labor between the Nizamiye and the Şeriat court when he issued a Nizamiye document of manumission, a matter under the jurisdiction of the Şeriat court. ${ }^{34}$

The court found Ali Eşref Efendi guilty on all charges, and sentenced him to six months imprisonment, beginning with his arrest on November 4, 1885, in addition to a fine of five liras. ${ }^{35}$ Since Ali Eşref Efendi had already spent the preceding six months in prison, awaiting his trial, the sentence handed down on June 2, 1886 actually brought this stressful period to a close. Comparing this sentence to penalties pre-

$31 \mathrm{CM}, 3,512$.

$32 \mathrm{CM}, 3,523$.

$33 \mathrm{CM}, 3,524$.

$34 \mathrm{CM}, 3,525$.

35 CM, 3,525-6. 
scribed by the relevant clause in the Criminal Code, the clause indicated in the court decision, it appears that the court was quite lenient. Clause 127 prescribed a penalty of one to three years imprisonment for misusing or tampering with state documents. Hence, the court imposed a lighter penalty than the minimum prescribed for this charge. Moderate as it may have been, the fact remained: this decision marked the banishment of Ali Eşref Efendi from the judiciary.

\subsection{Legal Formalism and Accountability}

Obviously, every trial has multiple layers of meaning, only fragments of which are revealed in the documentary traces left by court proceedings. Much of the hidden or overt agendas, behind-the-scene intrigues, and the passions that motivate human behavior, will always be left out of the judicial records. As far as microhistorical analysis is concerned, this truism is not an impediment; rather, it is a given. The judges who looked into the case of Ali Eşref Efendi were not interested in reconstructing the histoire totale of Ali Eşref's court and conduct; they were concerned with the specific connections that were relevant to their duty. Namely, they had to assess how his actions conformed with the letter of the law. In (a somewhat) similar manner, a microhistorical reading of the trial's verbatim report is not intended merely as an interesting story that happened in the past. Rather, it is aimed at understanding specific connections between the episode in question, marginal as it might be, and the larger scheme of things. Unlike the judge, however, the microhistorian has no interest in solving contradictions. ${ }^{36}$

The details of judicial practice exposed through the trial of Ali Eşref Efendi, as well as the decision to publish the full verbatim report in the Ceride-i Mehakim, convey two crucial elements of the ideology distinctive of the Nizamiye courts: legal formalism and the principle of accountability.

Obsession with procedure was one feature of the Nizamiye court system that qualified it as a modern legal system, distinguishing it from the preceding Şeriat court system, in which legal procedure was much simpler. In the late nineteenth century, Ottoman justice became increasingly associated with adherence to codified procedure. All judicial actions were regulated by hundreds of clauses inscribed in the procedural codes, to be applied uniformly by all courts. The difference between lawful and unlawful became contingent on strict application of the codified procedure. The legal legitimacy of every judicial practice was primarily assessed in terms of how it

36 For a comparison between the judge and the historian, see Carlo Ginzburg, The Judge and the Historian: Marginal Notes on A Late-Twentieth-Century Miscarriage of Justice (London, New York: Verso, 1999. 
conformed to a particular standard published by the Ministry of Justice or the legislature. The judiciary's observance of procedural standards was constantly monitored through the courts of appeal and the Court of Cassation. Annulment of court decisions due to often quite minor procedural failures was a widespread phenomenon. As in any other modern judicial system that endorses legal formalism, the elaborate procedure and the zeal with which it was enforced by the Ottoman central judicial administration provided those appealing to the court (hereafter, court users) with new means for contesting their adversaries. ${ }^{37}$ The ideology of legal formalism was indoctrinated among the judicial rank-and-file through daily circulars; through the publication of rulings issued by the Court of Cassation; and by treating significant violations of procedure as a breach of discipline. The intolerance of the central judicial administration to procedural compromises was entrenched in the principle of accountability, yet another attribute of the Nizamiye court system.

In the late nineteenth century, trivial violations of procedure and general negligence by judicial personnel were included in the category of official misconduct, along with more obviously unjust conduct, such as acceptance of bribes and brutal behavior towards court users and even colleagues. Court presidents and members were subject to criminal investigations, prosecution, and trials for violations of procedure. For example, the entire staff of the Hakkari court of first instance was prosecuted for forming a court committee (heyet-i hakime) not in accordance with procedure, and unlawfully releasing a suspect. ${ }^{38}$ An investigating magistrate in Amasya and the assistant public prosecutor of the same court were tried for delaying criminal cases. ${ }^{39}$ The president of the criminal section of the court of first instance in Sivas was prosecuted for holding up a single case for forty days. ${ }^{40}$

Ali Eşref Efendi's transgression was hardly minor. From a Nizamiye perspective, the severe deviation from procedure evidenced by his conduct undermined the very principle of the rule of law. The court was not impressed by his kindness, revealed not only in his treatment of Bezmihal, but also in his treatment of his subordinates. The other, less serious, charges against him should be also recalled. Ali Eşref was accused of permitting two of his subordinates to travel away for a week, although the authority to issue such permits lay with the Ministry of Justice, and not with the president of the court. In the court hearing, his attorney explained it as a matter of misunderstanding, emphasizing that they had traveled for the purpose of their weddings. ${ }^{41}$ It is difficult to ignore the pattern in Ali Eşref's behavior: in all these cases he acceded to the

37 Avi Rubin, "Legal Borrowing and its Impact on Ottoman Legal Culture in the Late Nineteenth Century," Continuity and Change 22 (2007), 279-303.

$38 \mathrm{CM}, 11,006$.

$39 \mathrm{CM}, 2,866$.

40 CM, 11,294.

$41 \mathrm{CM}, 3,525$. 
insistent pleas of individuals who needed his help, while taking the formalities rather lightly. Nevertheless, it appears that good intentions played no part in the formalist legal culture of the Nizamiye court system; the judges made it clear in their decision, arguing that his explanation was irrelevant.

\subsection{Conclusion}

The consequences of Bezmihal's appeal to the patron-state embodied in the Nizamiye court are unknown. To be sure, the price Ali Eşref was forced to pay for his compassion was considered appalling for any man of his position, since he forfeited his career and his good name. Bezmihal was returned to her master, perhaps to a miserable destiny of further beatings, as Judge Ali Eşref was no longer available to protect her. Perhaps the governor learned his lesson and improved his treatment of Bezmihal. Her determined behavior made it clear that she was not a passive victim to the whims of her master. Emin Bey's success in getting rid of Ali Eşref Efendi did not alter the fact that the patron-state was increasingly attentive to the needs of slaves, and willing to confront slave owners.

The "system" penalized Ali Eşref Efendi for compromising procedure, although no ill intentions were evident. It may be tempting to depict the harsh response of the system as yet another indication of the heartlessness of the modern, panoptic state, with its set-in-stone procedures, but this would miss the bona fide intentions of the reformers and the central judicial administration to cultivate a legal system that would curb arbitrariness. The motivation of Governor Emin Bey in initiating disciplinary measures against the judge was certainly different, yet there was nothing cynical in the words of the prosecutor Ali Haydar Bey: "Courts are founded and judges are appointed in order to carry out the rule of justice”. Prosecutor Haydar Bey was merely representing the Nizamiye conviction, indeed the conviction of other modern legal systems, which equated justice with legal formalism. Humane gestures were less relevant in that cosmology. 